\title{
China on Stage: Assumptions and Strategies in South China Sea
}

\author{
Victor Alexandre G. Teixeira ${ }^{1}$ \\ ${ }^{1}$ School of International Relations, Xiamen University, Xiamen, China \\ Correspondence: Victor Alexandre G. Teixeira, School of International Relations, Xiamen University, Xiamen, \\ China. Tel: 86-156-5998-2180.
}

Received: August 5, 2018

Accepted: August 15, 2018

Online Published: August 27, 2018

doi:10.20849/ajsss.v3i3.436

URL: https://doi.org/10.20849/ajsss.v3i3.436

\begin{abstract}
This study attempts to better understand the geopolitical, geostrategic, and geo-economic underpinnings behind the USA's so-called "Pivot to Asia" by analyzing the dynamics behind the South China Sea dispute. The emergence of Asia as the power epicenter of the world is the defining paradigm shift of our time; and China's meteoric economic rise was the determining factor behind this repositioning of geopolitical polarity. The study analyzes this dispute from the perspectives of the Containment Theory, Assumptions, Geo-Economic Strategies and Power. It also points out solutions to the conflict through international law and cooperation. Finally, emphasizes the importance of both, the geostrategic point of view and a geopolitical standpoint and has demonstrated that the US policy strategies towards Asia and the SCS are not helpful at all. Instead of focusing on containing China, the US should embrace China as a trading partner and become a neutral player in matters of the region including South China Sea.
\end{abstract}

Keywords: South China Sea, assumptions, US China relations, geostrategies, geopolitics

\section{Introduction}

The purpose of this study is to better understand the significance of the United States' "pivot to Asia" and to present sustained research on the dynamics and reasons for this change. The increasing geopolitical significance of Asia, including arguably the growing role of China as a stabilizing force, both in the region and internationally, represents a remarkable and historic shift. Despite the United States' unquestionable continuing dominance in world affairs, the "unipolar moment" turned out to be brief and, in fact, has already ended. The SCS has recently received much attention from the world due to the escalating territorial conflict in the region (Liff et al, 2016). The SCS is not only a strategic geographical location, but also has great potential of reserve in resources such as oil and natural gas, making it a hotspot for conflicts among the neighboring states and the US.

The conflict in the South China Sea is driven by the desire for control of natural resources between states claiming sovereignty over the regional archipelagos, such as the Spratly and Paracel Islands. The dispute in SCS is based on vital issues of territorial sovereignty, military security, economic development and political legitimacy for China and other claimants. The area has rich reserves of gas and oil resources that are well located near the large-scale energy-consuming countries. The ongoing search and exploitation for new oil reserves have been making the South China Sea one of the most controversial areas of the world. Furthermore, the South China Sea area is the international's second-busiest sea lane. Over half of the world's supertanker traffic goes through its Ethel waters (Navarro, 2016). The SCS has received increased attention as an important political region in recent decades.

Despite the natural resources and the importance of the sea line, the real reason of contests is the rising of China's Power. In other words, the ascension of China as a global and regional power shows an antithesis of the existing order. China's rapid rise as a great power stands for significant developments in the contemporary global system. In the near past, China has also made remarkable steps in its military modernization, but as Liff and Erickson (2013) noted, "China's budget transparency remains significantly lower than that of the United States and its major Asia Pacific allies, despite some recent progress".

The world and especially the south-eastern countries witness not only the emergence and Resurgence of China but also the development of the entire region with China as its driving force. Together with these rising capabilities, China has become more diplomatically involved, seeking to settle territorial disputes that have been there for a long time, to be more involved in international and regional institutions, and to grow their 
relationships globally, from Southeast Asia to Africa, and to Latin America (Fu et al, 2015). The growing power of China raises some apprehension, either regional or global. Despite the security dilemma, power transition theory (which highlights the likelihood for an unwelcome ascending power to challenge the prevailing international order) remains uneasy to evaluate if an ascending power is surely dissatisfied. China's growing desire towards regional cooperation with East Asia to boost trade and its rise has become a concern for its neighbors and the international community, particularly the US. As Fu et al (2015) stated, "The major drivers of the rapidly changing power balance in Asia are China's rapid military modernization and economic development. China's interests and capabilities have expanded and the growth of economic and military power can enable it to pursue their interests through military force or coercion. Regional countries are clearly concerned Chinese intentions as her military and economic capabilities continue to surge.

The sovereignty competition between China and its neighbors over territorial borders, resources, and security in the South China Sea have been going on for years. It has attracted the eyeballs of military and diplomatic leaders from other countries who are devoted to promoting stability and peace in these globally valuable and vital strategic waters. Japan, Vietnam, and the Philippines have ongoing disputes with China. Yet even these countries that may "most likely" be rivals have been part of muted military competition or arms race, as Steve Chan (2013) claims that most Asian political leaders do not regard it viable to enhance political legitimacy through military balancing against foreign enemies. This growth will continue with an increasing demand for energy, as Richardson (2008) noted, "Rapid growth and a resurgence of strong demand for energy in Asia will again push China and its Southeast Asian neighbors into contention".

This study is driven by two main research questions. The first is whether the role of the US is a problem or a solution for the conflicts in the South China Sea. The second is whether the strategy to contain China's power will succeed. To answer these questions requires us to examine the power that the US has over China and the rest of the world and its policies that are designed to ensure that it is not politically, economically, or militarily challenged. This study will also be based on the realists and liberalist theories of international relation. It is clear from a review of the literature that the consensus view among scholars is that the involvement of the US in the South China Sea disputes will not resolve it, but is itself rather a problem. This is because US policy is aimed at pursuing US interests, as defined by policymakers, which are not necessarily aligned with the interests of the parties to the South China Sea disputes (Kagan, 2017). Many parties themselves are opposed to US involvement.

The USA is turning to the Southern China Sea to meet its next strategic challenge after a decade of operations in the mountains and desert of Middle East. In particular, the US is keen to contain China's growing political, military and economic influence in the region. The US containment policy has resulted in increased military presence in SCS which is threatening trade and world peace as tensions continue to grow. A review of the literature with the aforementioned focus in mind brings important insights to scholarship in this area (Jeffrey et $a l$, 2014). Specifically, the finding of this review is that the US's containment strategy cannot work and that this policy serves as a destabilizing rather than a stabilizing influence in the South China Sea.

This paper will argue that use of diplomacy absent the threat of military intervention would be more beneficial to the growth and stability of both countries, as well as to China's neighbors in the South China Sea region. Specifically, what is required for peaceful and mutually agreeable resolutions to the territorial disputes in the South China Sea is for an abandonment of the containment policy and paradigm shift to recognizing China not as an enemy, but as a partner (Allison, 2017). This, in turn, would mean a policy of non-interference in the affairs of other countries, such as in the South China Sea disputes, absent mutually agreed invitation of the involved parties to assist in neutral mediation.

\section{Assumptions in SCS}

As a result of the dynamics surrounding the SCS, there is emergence of a number of assumptions regarding the region. One of the assumptions in SCS is that as time progresses china will become the full controller of the South China Sea. In this case, his assumption assumes that China will take over all the activities going on in the region and it will be entitled to the benefits that are associated to the area. According to the studies done, China has no possibility of taking over the region and gain control over it solely. There are a number of reasons attributed to the fact that china will not have the privilege of being the sole controller of the region. For instance, Vietnam is one of the claimants of the islands and resources available in the South China Sea that does not support the establishment of monopoly of the Chinese in the region (Jones et al, 2014). Studies show that in the event that china gets an opportunity to be the leader of the region, Vietnam is ready to give up some of acquired materials and regions to ensure that the presence of Chinese armed personnel around its borders is reduced. In addition, it should be noted that some of the East Asia countries have formed pacts with United States in return 
for security and benefits associated to the development of their economies. As a result of the alleged support in return for benefits in the event that China gets an opportunity to control the South China Sea, it will be faced by rivalry and lack of support from these countries thus eliminating china's full control assumption. Consequently, it is noted that most countries in the East Asia would want to retain a status quo therefore they would support America in the event that China was to be a monopoly force controlling the SCS. As a result of the lack of support, china would not be progressive in its venture hence not being a controller of the SCS.

The second assumption is that in the event that China got hold of the control of the region it would jeopardize the navigation freedom. The assumption of china threatening the navigation freedom is wrongly placed as there are laws put in place to control the activities taking places in around the sea. One of the laws regarding the sea is the UN Convection law regarding the sea whereby commercial activities are allowed to take place without implementation of barriers that can affect the freedom of ratifier states to pass their commercial goods through the waterway. The second law does not provide the activities that are elaborated in the law and those provided by the law. In that case, there is no existence of a provision that allows china to disrupt the freedom of navigation however the assumption is cleverly twisted to reflect that when the United states carry out surveillances, intelligence and reconnaissance activities with intent to challenge China, around the region and the china takes action against them it's freedom to navigate is violated which is not true. It is important therefore to note that, China lacks the ability to violate the navigation freedom of both ratifiers and non-ratifiers courtesy of the UN Convention Law of the Sea. In addition, a third great assumption revolving the SCS is that Washington acts as an honorable and worldwide frontrunner in encouraging and thought-provoking China to become a more accountable worldwide participant (Hill, 2014). The assumption that America is the leading force that can act to be a role model to china is misplaced and was established as a result of misplaced superiority complex. Studies prove that United States has not fully positioned itself to become the world's ethical role model, therefore the assumption that it can provide insight to China to be a responsible stakeholder in the world is inappropriate and lacks credibility. Consequently, the assumption has been as a result of the continued conflicts and wars in the United States thus proving that America's assumption of being a global leader and role model for china remains just that (Davies, 2012).

We should ask if china is a revisionist power or not? According to the studies done on the position of china in the globe, shows that its activities are inclined towards the status quo rather than the revisionist power thus conclusions are made that china is not a revisionist power. China has recently increased its activities in the international realm by helping different countries come into an understanding following their rows, also the country has been active in engaging in international activities such as trading as its productivity has recently increased, the country also has been involved in conventions and summits of the great 8 nations that are said to be the most industrialized in the country and finally it has associated itself with organizations whose role is to bring together different countries together to achieved a common goal for instance trading activities and peaceful treaties (Grygiel \& Mitchell, 2017).

In the recent past, China has been growing globally thus becoming an international power state. In addition to increased power increment and rise, China has become more active in the activities affecting the globe hence china is not a revisionist power. Observation of China's behavior shows that the country actively relates with institutions that are multilateral for instance, China is an active stakeholder in the Trade World Organization. The trade world organization is an organization that was established to ensure that there is a close integration between trading countries and activities in the world thus enhancing global trade (Hong et al, 2013). Consequently, to show that China is not a revisionist power, it recently started attending the G8 conventions for countries deemed to be industrialized. The result of the attendance proves that China has accepted and is satisfied with the positioning of the international relations. Studies and observations have shown that china has increased its participation in affairs of the globe and is highly associated with nations that are said to uphold the status quo.

Due to its growth both politically and economically, China has become more active in international trade. The country has attracted quiet a large part of foreign markets thus its exports have increased whereas it is demanding more foreign commodities thus imports are also increasing. During international trade there are terms and conditions that the participants should follow and adhere to in bid to avoid conflicts and emergence of hostile environments. In that case, China has accepted the rules and terms of international trading thus proving that it feels comfortable with the existing relations present in the world hence eliminating the possibility of it being a revisionist power. Consequently, Beijing is on record voicing its support to the international relations through offering its support to respect of territories, protecting the internal affairs of a nation and maintain sovereignty of states. This acts as a reflection of the activities and the support alienation being provided by china at the international and global level thus China proving further that it is not a revisionist. Finally, China has proved to 
not being a revisionist power as it is actively being involved in helping solve problems associated to territories. For instance, China was involved in solving a territory dispute of the border between Russia and Sino. In addition, China has been involved in resolving some of the issues that were posing as threats to India's political and economic stability. In the case relating to the South China Sea, China has come up with different strategies of ensuring that the conflict between the contesting states is reduced thus lowering the possibility of eruption of a war. China has resolved to use more peaceful and diplomatic ways of dealing with the impending hostility among the countries that are claimants of the South China Sea (Maegaard et al, 2014).

\section{The US Policy' Strategy}

Recently the world has witnessed the creation of Xi Jinping's personal political ideology; which will entrench his position in the legacy of the Communist Party on a footing equal to that of Mao Zedong or Deng Xiaoping. Xi's "theory" emphasizes China's nascent ascension to the status of a great power, as can be evidenced through such statements by Xi himself as "It is time for us to take center stage in the world and to make a greater contribution to humankind" (Martel, 2017). This shows a leader with confidence asserting that his country has already become a great power; while also reinforcing china's political culture. For Xi Jinping, China's socialist democracy is the world's most genuine and most effective democracy to safeguard his people; China doesn't need to copy any other political system. Regarding the South China Sea, Xi Jinping noted that the artificial islands were a significant development of the last five years; heightening tensions with other stakeholders, including the United States (Martel, 2017). The President also noted that China is not seeking conflict, but nonetheless highlighted the reorganization of China's military as a significant achievement over the last five years and further promised continued changes including increasing the professionalism of officers and improvements in weaponry; promising that China's military capabilities would be first class in all fields.

A few hours later, the United States Secretary of State, Rex Tillerson said 'America would deepen cooperation with India in the face of a growing Chinese peril in Asia'. According to Tillerson's speech as given at the Center for Strategic and International Studies, China is a non-democratic society and America should recognize India as a potential partner in a strategic economic and political relationship that could never happen with China (Tillerson, 2017). In Tillerson's words, China has sometimes acted outside of accepted international norms; and gave the South China Sea Dispute as an example. In Tillerson's words: "We will not shrink from China's challenges to the rules-based order and where China subverts the sovereignty of neighboring countries and disadvantages the US and friends" (Tillerson, 2017).

\subsection{Containment Strategy}

Taken together, it would seem that Asia has become a priority in American foreign policy, politics, and ideology (Ikenberry, 2016). Asia is transcending the present dimensions of geopolitical power and restructuring the dynamic of geopolitics towards one that focuses on economic efficiency rather than military might.

America's concern with the South China Sea is not merely due to any fear of a potential military escalation in the region or even commitment to treaty allies; rather America's involvement in the dispute is an attempt to contain an ascendant China. In other words, China's nascent ascension to the status of a regional and global power represents the antithesis of the established global order which threatens America's own hegemony. Containing China is a platform held up by two pillars, one geopolitical and one geostrategic. Geopolitically, containing China reduces her to the status of a regional power. Geo-strategically, containing China ensures the continuing dominance of the American hegemony. This view is supported by Peter Navarro (2016) who observes, "The United States does not tolerate peer competitors. As it demonstrated in the twentieth century, it is determined to remain the world's only regional hegemony. Therefore, the United States can be expected to go to great length to contain China".

According to Peter Navarro, America's major concerns in Asia is not finding a resolution to the Southern China Sea conflict, but balancing Chinese growing influence. The US policymakers' obsession with China's growing popularity is ill-advised and bound to bring more harm than good.

The question is, does the Containment Strategy Mitigate Issues in the SCS?

The theory of containment was imposed by the US to prevent the spread of Soviet idealism after the Second World War. This theory speculated that any country that adopted the Soviet influence could subsequently influence all neighboring countries through a domino effect (Mearsheimer, 2017). In other words, the US government has become used to considering the world, especially after the Cold War, as if it were a chessboard, albeit a board on which it is the only player in the game and the others are pieces (Mearsheimer, 2017).

Since its foundation, the US has consistently oriented its strategy toward the acquisition and maintenance of its 
predominant power over its rivals, first in the north region of the USA continent, then in the European hemisphere and, finally, globally. This strategy was called containment during the Cold War (Mearsheimer, 2017). This policy of containment is composed of several dynamics that involve treaties of mutual security, limiting access to natural resources and preserving the military, economic and technological supremacy of the US.

\subsection{An Alternative System}

The US created an international system designed for its interests and to maximize its national power. These dynamics are based upon three dimensions: political, diplomatic and military. The US Military is working to contain China in Asia even though political leaders of the country continue to deny it. American policy-makers have developed a strategy that would check Chinese surging military and economic power. US military forces could threaten China's trade through the Southern China Sea (Mearsheimer, 2014). The raw materials and oil transported through the sea lane in Southern Sea China are crucial to the rising Chinese economy.

China is believed to be designing an alternative international system to weaken the existing standard system, as highlighted by Robert and Tellis, "a variety of similar bodies that privilege China's position and Undermine standards of governance set by the Organization for Economic Cooperation and Development (OECD), the World Bank, and other international institutions" (Blackwell and Tellis, 2015). What analysts do not see or do not want to see, because they have been moulded by the assumption that the US is the sole superpower (i.e., "American exceptionalism"), is that the institutions created by China and their initiatives will not undermine the international system and will constitute alternatives not only to China but also to other powers (Walt, 2011).

Contrary to the assertions by policymakers inside pentagon that US is only concerned about the escalating territorial conflicts in the SCS, Ikenberry (2016) noted that the strategy of the US is to enhance its military presence with military and naval training, diplomatically supporting any discretion of neighbouring and allied countries in the United Nations, financially supporting these states, sharing new technologies and trying new trade agreements.

Over the last twenty years, the China and USA diplomatic relations have significantly improved save for few mishaps that tended to derail the Sino-US relations projection. The last five administrations have tried to maintain a neutral position to the South China Sea dispute by choosing a neutral language to avoid being entangled in the border dispute. The speeches by senior US administration officials more often than not carry a disclaimer that the USA seeks to choose no sides in the SCS border dispute and wishes to resolve the border disputes in the SCS to be reached without coercion (Fu et al, 2015). This effort which is impartial however is difficult to maintain since the USA seems to be drawing many countries in the SCS border dispute to its political-military sphere except China.

With its vast resources and reach globally, the US Navy has the ability to represent its face fully in the Pacific region. However, when it comes to China the US Navy has been unable to engage its emerging naval power (Ikenberry, 2016). The US Navy fleets in the Pacific region conducts over 700 port calls for scheduled maintenance, crew liberty, and engagements thereafter. The USA flag on the naval warships is a powerful symbol and a sign of the strength of the USA relationship with the countries they make that port calls on, a tool they have employed in the past century successfully. Since 1993 to 2011, the US Navy has however made fourteen (14) port calls to China, which is relatively low compared to over 13,000 in the surrounding countries in the SCS in the same span portraying the political difficulty in permission obtaining for such visits in the country (Chan, 2013). It also portrays the inability or reluctance of the USA to make relationships with China as it has been successfully able to do with other countries in the SCS border dispute.

Is this strategic three-dimensional dynamic of the US sufficient to contain the relations between the states mentioned above and China? Does it offer any help towards regional territorial peace in the SCS?

According to Ikenberry (2016), this strategy is not sufficient, and containing China is useless. China is already a world and regional power as many studies have indicated. The US response follows the military dynamics, increasing and strengthening its presence in the region and increasing the ability of its allies and partners in the region. However, based on the analysis of Ikenberry (2016), shows that this strategy of containment failed and that even the unquestionable US military supremacy is not effective as an influence in Asia; the economic dimension is more influential than the military power. Beijing has launched several successful economic initiatives, as mentioned above, and the AIIB already has 70-member countries and heads the negotiations at the regional Comprehensive Economic Partnership (RCEP), some trade alliances in the region that aims to gather the ten ASEAN member countries, including China, Australia, New Zealand, India, Japan, and South Korea. It is notable that this group represents almost half of the world's population, slightly below the level of the world 
GDP (Ikenberry et al, 2017). Even if the agreement is not reached, the RCEP is the new "game" in which the US is not present. China's initiatives are important given its regional impact and the fact that it induces the perception of inevitability in relation to the economic future of the sub region under Chinese leadership. A recent study by Ikenberry et al (2017) has shown that the South Asian countries are aware that the US is losing ground and that the Trump administration is not interested in the region and is unlikely to sign a free trade agreement.

\section{GEO-Economic Strategy}

Geo-economics is defined by Allison thus: "Geo-economics, which is the use of economic instruments (from trade and investment policy to sanctions, cyber-attacks, and foreign aid) to achieve geopolitical goals" (Allison, 2017). Robert Blackwell and Jennifer Harris in their book "War by Other Means: Geo-economics and Statecraft" offer another definition: "it's not using economic tools for economic purposes, although those are fine, notable objectives. It's using these economic tools to advance a government, a nation's geopolitical interests" (Blackwell \& Harris, 2016). There is nothing novel in this strategy, countries of the past and present have employed and continue to employ geo-economic strategies as a means to achieving their goals. Russia frequently uses her energy resources as leverage over other nations, and an economic sanction is a tool frequently employed by the USA in pursuing her geopolitical interests. Both these nations and others use state-owned or iconic companies to achieve geopolitical ends. The increased focus towards Geo-economics in political dialogue today has occurred due to China's ongoing and successful use of this stratagem.

\subsection{The Trade Strategy}

According to Robert (Blackwell \& Harris, 2016)), to counter the possibility of China's successful use of geo-economic stratagem, the US is using the Trans-Pacific Partnership (TPP) as outlined by the Obama administration and withdrawn by the Trump administration in a first phase, although there is current consideration of whether the agreement should be amended. Trump has stated, "I would do TPP if we were able to make a substantially better deal. If we did a substantially better deal, I would be open to TPP" (Trump, 2018). Shiro Armstrong contended that the benefits of the TPP are poor, indicating that the nature of this agreement is more political than economic. The TPP can be characterized as a preferable excluding agreement, a regional arrangement, in which a large world power such as the United States, should contribute more to the development of investments and global trade, than blocking the initiatives in progress of other regional powers, such as the ASEAN. It is argued that "perhaps the biggest issue is that the TPP is in many respects fundamentally a political and a security tool" (Armstrong, 2011).

TPP is the American economic backbone in its 'pivot to Asia strategy' and it is important to note how China was left out of the negotiation process (Blackwell \& Harris, 2016). Leaving China out of trade deals in Asia only jeopardizes any chance of solving the SCS dispute. China is a major player in the conflict, the US formation of alliances with other disputants except China is a miscalculation. It only highlights USA's possibly wrong approach to the regional matters. The US has in many occasions insisted that in their deals in TPP is not a deal targeting to contain China, but to set new global standards as President Obama stated on October $15^{\text {th }}, 2015$ : "We can't let countries like China write the rules of the global economy. We should write those rules". Among other purposes, the TPP serves as a tool to curb growing China's economic dominance in Asia. As Walt pointed out, "although, of course, the TPP will not erase China's asymmetrical economic advantages with respect to the nations of Asia, it will be a vivid demonstration that the United States is determined to compete on the Asian economic playing field". The TPP may act as either a lucrative opportunity for China or her challenge. The chance for the inclusion of China is still open as noted by Japan's Prime Minister Shinzo Abe when he said, "it would have significant strategic meaning if China joined the system in the future" (Armstrong, 2011). With the current stated conditions for membership, China may, however, be unable to join unless it undertakes significant reforms in the near future. Additionally, there are other challenges for China joining TPP as the FTAs which negotiated in Asia. China on its part has established its political standing for 'Greater China' by signing FTAs with Taiwan, Macau, and Hong Kong.

During President Obama's administration, the US became closer to Vietnam as a key piece in the US-designed containment policy, in which Vietnam plays a three-dimensional role. As far as the economic dimension is concerned, Vietnam is a member of the Trans-Pacific Partnership (more precisely, a free trade agreement), which intentionally excludes China. In view of the diplomatic dimension of containment, Vietnam supports the Philippines against China in the dispute over the South China Sea and emphasizes cooperation among the member countries of the ASEAN as a legitimate regional forum. Lastly, as far as the military containment dimension is concerned, the US raised the arms embargo and simultaneously increased financial support for the maritime development of Hanoi which shows the importance of Vietnam for the US containment strategy. The 
Philippines is not a member country of the TPP; Japan is not present in the ASEAN; and Vietnam has evolved from an enemy to a US strategic partner, which makes Vietnam an imperative piece of the US strategy (Armstrong, 2011). However, Vietnam has solid relations with China, so it acts independently. This occurs because Vietnam does not want to be under the influence of any of the powers. Vietnam prefers combining relations with the US and with China to opting for a direct commitment to any of the superpowers. Vietnam emphasizes cooperation with several states simultaneously, such as Russia, Japan, and India. This multi-cooperation enables Vietnam to take its own independent position in a new world that is no longer unipolar.

As Armstrong (2011), notes the US policies have already created a rift in the region. This is true as a parallel China's FTA with Australia and Pakistan has been finalized and signed while the one with ASEAN member countries is still in progress in order to propel China's relations and regional links with her neighbors. More recently, ambitious trading negotiations have been launched with South Korea, India and Japan. The Regional Comprehensive Economic Partnership (RCEP) is also a major component of China's web of Asian FTAs. The negotiations began in 2013 and brought together some ASEAN members, including Japan, India, New Zealand, China, Australia and South Korea. However, the conclusion of this TPP may push non-members to form strike a deal that would balance economic impacts of the latter TPP (Armstrong, 2011). Also, as a major geopolitical component, the RCEP would allow China broaden its ties through major trade deals that do not include the US.

\subsection{Preventing a Chinese "Exceptionalism"}

According to Kupchan (2012), the United States, and not China, may be the catalyst for any potential conflict. The West may actually concern ourselves too much with the internal nature of the Chinese regime and seek to limit China's power abroad because simply they care less about their domestic policies. In other words, the strong belief in "American exceptionalism" has deterred the country from accepting the new power as the new "exceptionalism". Digressing from whether China's interests are valid or not; China's pursuit of its own geopolitical interests are certainly no more provocative than those of any other major power, including the United States Kupchan (2012). China merely seeks to establish its own "Monroe doctrine" as regards securing its own interests in the geopolitical corner of the world it occupies. As Kupchan (2012) observed, "Just as the United States unfurled the Monroe Doctrine to ward off European powers that challenged U.S. hegemony in the Western Hemisphere, China is set to lay claim to a sphere of influence in Northeast Asian and guardianship of the region's vital sea lanes". How China's rising confidence may affect American regional interests in Southeast Asia region depends on how U.S. interests in the region are defined. The traditionally considered US's key Southern Asia region interests are: promotion of balance and stability of power: with the main objective of keeping Southeast Asia from being solely dominated by any hegemony; prevention of itself from being edged out of the region by another power or group of powers; protection of sea lanes and freedom of navigation; trade and investment interests; supporting treaty friends and allies; democracy promotion, rule of law, religious freedom, and human rights. A recent addition to this list is the prevention of the region from becoming a base for support of terrorists. The same cliché the U.S always has, they never say their real purpose aloud. America's intention is to suppress the Chinese rise and to prevent a transition of power in the future (Schweller, 2006). Scholars like Mearsheimer (2014) shared my opinion "United States has a critical interest in providing reassurance to its allies and partners in the region that it will maintain a strong security presence to prevent a power vacuum from developing as China rises".

United States strategy is to prevent the rise of China; Mearsheimer (2016) in an interview supported "the United States will, therefore, form a balancing coalition in Asia, which will include most of China's neighbors and the United States. And they will work overtime to try to contain China and prevent it from dominating Asia".

The United States' own interests in the region are diverse. To begin with, the U.S. Navy has long dominated this maritime region, which is a crucial pass for the U.S. warships cruising from the Pacific to the Middle East. The treaty between the United States and Japan also obligates the US to defend Japan and its maritime lifelines (Schweller, 2006). Therefore, freedom of navigation in the East and South China Seas is a declared U.S. national security priority. China has not yet made the implications of its rise felt on the international scene, and it is as yet unknown what China's true intentions are regarding the established international order, who is to say whether or not China is a revisionist country and a truly dangerous aggressor. One does not observe China declaring itself a "balancer" to the actions of Russia, the US, or any other great power. Actually, according to Schweller (2006), America pivot is to contain China however, this may even be a case of "overbalancing," the US reading too much into the actions of China and overestimating the value of these actions upon the world order, thereby seeking to impose its self, thus triggering an arms spiral with China. 
Schweller (2006), in his brilliant work, "Unanswered Threats", defined: "Overbalancing (or inappropriate balancing), which unnecessarily triggers some costly and dangerous arms spiral because the target is misperceived as an aggressor but is, instead, a defensively minded state seeking only enhance its security". History has numerous examples of such can lead to disputes that could potentially transform into conflicts.

The policy of engagement and containment by the US government towards China has in the tail end of President Obama's administration elicited different views after the Secretary Defence visited India and signed bilateral agreements on military logistics in Mid-April. President Obama later visited Vietnam and announced a lifting of the weapon embargo to Vietnam (Kagan, 2017). The US senior officials always insist that their bilateral agreements with Vietnam aren't meant to contain China, but such words lack credulity when viewed against the blunt reminders to China on its security obligations to the Philippine as per their bilateral defense treaty.

The containment policy by the US to China has accelerated recently as a result of China's ascending influence in the region and globally. Much emphasis is put on the view of China (by the USA) as a competitor, if not a full-blown rival. China and the US are trading partners with China importing goods worth $\$ 116$ billion from the US while exporting goods worth $\$ 482$ billion to the US in 2015 and their bilateral economic relationship is crucial and extensive (Kagan, 2017). Despite inflammatory remarks in the recent past towards China by President Donald Trump and other critics, disruption of this economic interdependence between these two countries would be mutually costly.

A repeat of the containment strategy employed towards USSR in the cold-war era won't work if used in China. During the cold-war era, the economic interdependence between the US and USSR were negligible as opposed to those enjoyed today between China and the US.

It will also be difficult for the US to successfully assemble dependable alliance(s) against China. Implementing a containment policy against the USSR was quite possible during the Cold War because neither the US nor its allies had much to lose (Kagan, 2017). The political and economic costs of containing Moscow were therefore minimal. This, however, is a bit tricky with China. Most of US allies in the Middle East such as South Korea and Japan have massive economic dependence with China. Japan's leading trade partner is China. It would not be easy for Japan to lose a major trading partner is support of a confrontational US policy (Kagan, 2017). Even though Japan has concerns about China's approach in South Sea China, it would still be non-committing to participate in a hostile containment strategy.

The containment policy against the USSR during the Cold War proved difficult for US leaders as time passed. That was true especially in 1970 when Germany's Ostipolitik policy sought better relations with Moscow, East Germany and the rest of Soviet bloc. The deepened connections grew USSR and democratic Europe; support for the hard-line US strategies began to fade. The fading US support was evident in 1980's when the US attempted to persuade European allies to decline a proposal for the establishment of a pipeline from the USSR to Western Europe, fearing that the project would give Moscow unwarranted degree of policy influence. Key European allies rejected that request much to the disappointment of the US.

According to Blackwill and Tellis (2015) America continues to assemble support for a containment policy against China, it faces minimal chances of success. Few countries that are more reliant on US support may welcome the idea, but large powers may not make firm commitments that may antagonize their ties with China. The containment policy against China is, therefore, a poor option for the US. It will be difficult to solve the SCS and other regional issues without the substantial input from China (Mearsheimer, 2017). It's nearly impossible for example to picture an end to the territorial disputes in SCS without corporation from China.

A consideration of Chinese worldwide view is important in dealing with China's issue of growth. The Chinese are very acute in their history and are quite aware that for many centuries, they see themselves as victims of imperialist domination. As a result, the Chinese leadership do not trust the Western states and are convinced that the western states are out to contain its ambitions to gain a status in the world.

With that said, a liberal approach to China and the Southern China Sea disputes would be the most productive approach. The US by deepening its Chinese ties and taking a less than aggressive approach towards China, it plays to Chinese sensitivities and mitigates potential misunderstanding that can cause conflicts. If China feels that they receive the respect they deserve and are included in regional security arrangements, they would probably be more supportive of the US strategic policies. Political institutions would surely be liberalized by the continued economic growth. Chinese would easily support liberalization of world institutions as they seek to gain influence in international matters.

On the contrary, the realist's approach would antagonize China and lead Beijing to believe that the west is out to 
suppress its growth. China does not possess sufficient military power to directly confront the US, but American policymakers view Chinese military development as threatening. However, the US treating China as an enemy would lead China to respond in kind. Beijing would build a military to challenge the US presence in Asia while seeking ties with other countries that feel dissatisfied with the US hegemony.

China is strategically working to gain power across the world and gaining control of the SCS is fundamental in gaining national dignity. However, China does not seek to alter the international system of relations and can be useful as a member of the world's security community. The liberal policy can easily help achieve such an objective. When the time comes when China finally shakes the world, it will do so along with the West rather than against.

\section{Conclusion}

Provincial inquiry used to be the most legitimate hazard to security. Similarly, a multilateral level-headed discussion has ended up being more unsafe and complex in the SCS. Today, the most local level-headed discussion is latent and thus a less unique wellspring of contention. In the context of the increasing criticalness of the ocean resources and the globalization of the world economy, regional countries tend to give more importance to the maritime inquiry. China sees the SCS as lost spaces that should be territorial parts of China again, like other lost districts, such as the Diaoyu/Senkaku Islands in the East China Sea (Mearsheimer, 2014). In any case, by taking a more discernible power position in this district, China exposes issues related to its complex nature of vitality.

China presents itself as a major power set on building a friendly world during its peaceful climb. Thus, the need for cooperative neighboring countries is perceived while addressing claims in the SCS. This indicates Chinese determination; however, there is no sign that China is putting it all on the line by surrendering its private money related to improvements through a coercive methodology in the SCS conflict. I suggest that China will expect a central part, paying little regard to the possibility of war or investment in the SCS. With the increase of its ocean fiscal interests, such as resources, sea power, and legal limits, China is depended upon to become more unequivocal in the coming years. Meanwhile, the CCP expert observes that more imperative political interests should be considered. Along these lines, the appearance and improvement of Chinese insistence will no doubt be incremental and confined (Richardson, 2008). Chinese earnest exercises do and will certainly continue to produce uneasiness in South-eastern Asian states and require these regional states to make countermeasures, perhaps with unquestionable or unequivocal assistance from external forces, such as the US.

Of course, given the Chinese emphasis on East Asia and the CCP's need for private money related to progression, China could use its muscle in a limited way and maintain a vital separation from any sudden acceleration of its maritime inquiry in the SCS. As noted above, prompt results from the China-ASEAN Free Trade Agreement (CAFTA) with regard to monetary estimation are necessary for addition to another dynamic related to establishing peace and reducing the escalation of conflict between the claimants. China joins a fragile influence with a hard influence, which implies a sharp influence. This, together with money-related affiliation, conveys another dynamic into the SCS discussion. In the coming years, the Chinese capacity to modify its developing penchant to show the surer position and its political energy toward joint effort will be tested (Richardson, 2008). It will similarly be a test for South-eastern Asian inquirer states to respond to the changing Chinese methods to manage conflict. In light of misunderstood standards concerning the SCS, the DOC may well be the best option for the diverse solicitor states because it establishes the possibility of maintaining existing conditions, which may be the foundation for a future arrangement of standards.

The inevitable destiny of the SCS question is the maintenance of existing conditions, in which talks are defended calmly and focused on specific issues. One could argue that this condition is adequate for now and that the inquirers may continue to satisfy their people with remarks and clarifications while avoiding equipped conflict in light of the political and fiscal costs involved (Shambaugh, 2004/05). This means living with the standard until improved political and financial relations reduce strains and the likelihood of a political power establishing that no country has a perfect claim to the SCS; thus, there must be exchange to identify verifiable principles to make sense of it. The US has played a basic part in empowering security in South-eastern Asia: "America`s point in Asia should be changed, not quality." This would involve a plan for the ASEAN states to attract a rising China and a different way.

While seeking shelter behind the ASEAN judgment, the South-eastern Asian inquirers perceive Chinese activity and Beijing's semi-hegemonic position in the South China Sea is due to individual game plans that empower them to appreciate resource examination and obtain offers in the race for essential supplies. If the US needs to rebalance its powers worldwide, there will undoubtedly be validity. The landing of Asia at the point of 
convergence of overall issues is the advancement of the 21st century (Shambaugh, 2004/05). Trump's journey to Asia was a push to change the requirements of the American remote approach to the importance of the area as time passes as well as a message to China that could be avoidable.

Regardless of the competitive positions of both sides, the Chinese-US cooperation will benefit both countries in various fields. Examples of such fields include trade, energy security, climate change, financial stability, and pandemics. The region will also reap the fruits of cooperation. The stop-and-go tour of the Trump administration in Asia is a sign of the recognition of the great potential of the region and of a more powerful nation, China.

The heart of the SCS dispute is not oriented toward natural resources but rather toward the growing power of China as a risk to the status quo position of the US as the leader of the present world order (Nye, 2011). As a regional hegemonic potency, China, like any nation in a comparable position of power, feels the need to defend its interests, such as boundary claims in the South China Sea.

In the pursuit of geopolitical interests, China is certainly no more provocative than the pursuit of any other major power, including the US. China raises a question: if the US can propose a Monroe Doctrine for its interests, why can China not develop its own corollary for its own geopolitical interests? The US's response seems not to be alarm about how China pursues its interests but rather alarm about the fact that China should have interests and seek to secure them in the same way as the West.

To further illustrate this lack of perspective of the US, let us consider the conflict in Crimea. Some years ago, NATO expanded its influence into Eastern Europe, and Russia protested the influence of Europe and the US through expansion in other ways, such as through the diffusion of Western institutions and social media into Ukraine. Western expansionism was a political mistake, as Mearsheimer noted: "Russian leaders have adamantly opposed NATO enlargement and in recent years...have made it clear that they would not stand by while their strategically important neighbor turned into a Western bastion. For Putin, the illegal overthrow of Ukraine's democratically elected and pro-Russian president - which he rightly labeled a 'coup' - was the final straw. He responded by taking Crimea, a peninsula he feared would host a NATO naval base and worked to destabilize Ukraine until it abandoned its efforts to join the West. Putin's pushback should have come as no surprise. After all, the West had been moving into Russia's backyard and threatening its core strategic interests" (Mearsheimer, 2017). The crises in Ukraine and the annexation of Crimea are the results of Western overexpansion at the expense of the interests of other geopolitical players.

This indicates a larger trend demonstrated in the behavior of the present-day Western geopolitics, a sort of unilateralism in which Western narrative building and Western interests and values prevail over any other. This is an epistemological Western arrogance or bounded rationality in which something seen as prima facie correct from the perspective of the West must be true despite contrary evidence from outside the West; the Western perspective is a priori correct. Although this does not imply that non-Western perspectives are necessarily correct, it establishes that outdated Western attitudes toward non-Western players show that the West does not understand that the power and influence of non-Western great powers are such that they can move to secure their interests in today's world in a way that they could not have done previously. In other words, the West does not seem to realize that non-Western great powers exist, so present-day conflicts of interest cannot be handled as they were in the past (that is, through unilateral Western action). Such direct interventions, regardless of their aims, have always been provocative and heavy-handed (Allison, 2017). The difference nowadays is that the power of those who are subject to such interventions is comparable to the power of the West, so these manoeuvres - even if their intentions are altruistic inherently ignore the ramifications of imposing one's perspective on someone else prepared to defend their point of view with exactly the same means - to speak less of the consequences of a lack of altruistic Western interventions.

This is entirely applicable to the unfortunate events in the SCS. The US should not engage China through unilateral attempts to contain China's growth or curb its influence. Such actions, regardless of their motivation or intent, will only encourage China to buck the established institutions of the present-day world order in favor of the new ones. If China perceives that it cannot rely on the present institutions' impartiality, this will strengthen the narrative that such institutions hold an inherently Western bias, thus pushing China to seek other ones. The US should seek alternative means to engage in the dispute (Nye, 2011). This hinges upon two pillars. First, the US should not seek to impose an impasse on China's ascension as a military and economic power to resolve conflicts. Second, the US should seek to engage China in the SCS dispute by encouraging China to be involved in peaceable, bilateral negotiations with its neighbors, as the US did in the past with the Treaty of Portsmouth or the Camp David Accords.

\section{References}


Allison, G. (2017). Destined for War: Can America and China Escape Thucydides's Trap? (pp. 69-70). Houghton Mifflin Harcourt.

Armstrong, S. P. (2011, December 9). Australia and the Future of the Trans-Pacific Partnership Agreement. EABER Working Paper No. 71. Retrieved from https://ssrn.com/abstract=1970129 or http://dx.doi.org/10.2139/ssrn.1970129

Blackwell, R. (2016). War by other means: Geo-economics and statecraft. Council on Foreign Relations. Retrieved from https://www.cfr.org/event/war-other-means-geoeconomics-and-statecraft.

Blackwill, R. D., \& Tellis, A. (2015). Revising U.S. Grand Strategy Toward China. Council on Foreign Relations Press.

Buszynski, L. (2010). Rising Tensions in the South China Sea: Prospects for a Resolution of the Issue. Security Challenges, 6(2), 85-104.

Chan, S. (2013). Economics trumps Politics. Enduring Rivalries in the Asia-Pacific, pp. 134-156. Cambridge: Cambridge University Press.

Davies, R. W. (2012). The Era of Global Transition: Crises and Opportunities in the New World. New York: Palgrave Macmillan.

Fu, T. R., Gill, D. J., Hundman, E., Liff, A. P., \& Ikenberry, J. G. (2015). Correspondence: Looking for Asia's Security Dilemma. International Security, 40(2), 181-204.

Glaser, C. L. (1997). The Security Dilemma Revisited. World Politics, 50(01), 171-201.

Griffiths, R. (2015). Robert D. Kaplan: The South China Sea is to China what the Greater Caribbean was to the United States. The Globe and Mail. Retrieved from https://www.theglobeandmail.com/opinion/munk-debates/robert-d-kaplan-the-south-china-sea-is-to-china-w hat-the-greater-caribbean-was-to-the-united-states/article25039063/?arc404=true

Grygiel, J. J., \& Mitchell, A. W. (2017). The unquiet frontier: Rising rivals, vulnerable allies, and the crisis of American Power.

Herz, J. H. (1951). Political realism and political idealism, a study in theories and realities. Chicago: University of Chicago Press.

Hill, C. W. (2014). International business: Competing in the global marketplace.

Hong, B., Meng, X., Chen, L., Winiwarter, W., \& Song, W. (2013). Database Systems for Advanced Applications: 18th International Conference, DASFAA 2013. International Workshops: BDMA, SNSM, SeCoP, Wuhan, China, April 22-25, 2013. Proceedings.

Ikenberry, J. G., Lim, D. J. (2017). China's emerging institutional statecraft, the Asian Infrastructure Investment Bank and the prospects for counter-hegemony. Brookings Institution. Retrieved from https://www.brookings.edu/wp-content/uploads/2017/04/chinas-emerging-institutional-statecraft.pdf

Ikenberry, G. J. (2016). Between the Eagle and the Dragon: America, China, and Middle State Strategies in East Asia. Political Science Quarterly, 131, 9-43.

Jervis, R. (1978). Cooperation under the Security Dilemma. World Politics, 30(2), 167-214.

Jeffrey, A., Bader, K. G., \& Lieberthal, M. M. (2014). Report "Keeping the South China Sea in Perspective”. https://www.brookings.edu/research/keeping-the-south-china-sea-in-perspective

Jones, D. E., Marion, M., \& Miller, M. (2014). The dynamics of cultural counterpoint in Asian studies.

Kagan, R. (2017). Avoiding War: Containment, Competition and Cooperation in US-China Relations. Retrieved from

https://www.brookings.edu/research/avoiding-war-containment-competition-and-cooperation-in-u-s-china-r elations/

Keohane, R. O., \& Nye, J. S. (1977). Power and interdependence: world politics in transition. Boston: Little, Brown.

Kupchan, A. C. (2012). No One's World, the West, the Rising Rest, and the Coming Global Turn. Oxford: Oxford University Press.

Liff, A. P., Andrew, S. E. (2013, December). Demystifying China's Defence Spending: Less Mysterious in the Aggregate. China Quarterly, 216, 805-30. 
Mackinder, H. J. (1996). Democratic ideals and reality: a study in the politics of reconstruction. Washington, DC: National Defence University Press.

Maegaard, P., Krenz, A., \& Palz, W. (2014). Wind power for the world: International reviews and developments.

Martel, F. (2017). Xi Jinping Rallies Communists in three-hour speech: Time for us to take centre stage. Retrieved from http://www.breitbart.com/national-security/2017/10/18/xi-jinping-rallies-communists-speech-time-take-cent er-stage/

Mearsheimer, J. J. (2001). The Tragedy of Great Power Politics. New York: W.W. Norton \& Company, Inc.

Mearsheimer, J. J. (2014). Can China Rise Peacefully, Why China's Rise Will Not Be Peaceful. Retrieved from http://mearsheimer.uchicago.edu/pdfs/A0034b.pdf

Mearsheimer, J. J. (2017). "Why the Ukraine Crisis Is the West's Fault." Foreign Affairs. Retrieved October 13, 2017, from https://www.foreignaffairs.com/articles/russia-fsu/2014-08-18/why-ukraine-crisis-west-s-fault

Navarro, P. (2016). Mearsheimer on Strangling China \& the Inevitability of War. Huffpost. Retrieved from https://www.huffingtonpost.com/peter-navarro-and-greg-autry/mearsheimer-on-strangling_b_9417476.html

Nye, J. S. Jr. (2011). The Future of Power. New York: Public Affairs.

Richardson, M. (2008). A Southward Thrust for China's Energy Diplomacy in the South China Sea. The Asia-Pacific Journal, 6(11).

Schweller, R. L. (2006). Unanswered Threats: Political Constraints on the Balance of Power. Princeton University Press.

Shambaugh, D. (2004, May). China Engages Asia: Reshaping the Regional Order. International Security, 29 , 64-99.

Spykman, N. J. (1942). America's Strategy in World Politics: The United States and the Balance of Power. New York: Harcourt, Brace and Company.

Spykman, N. J., \& Helen, R. N. (1944). The geography of the peace. New York: Harcourt, Brace and Co.

Tillerson, R. (2017). Defining Our Relationship with India for the Next Century. Retrieved from https://www.csis.org/events/defining-our-relationship-india-next-century-address-us-secretary-state-rex-tille rson/?block4

Trump, D. (2018). $\quad$ CNBC. Interview. Retrieved from https://www.cnbc.com/2018/01/25/trump-says-he-would-reconsider-trans-pacific-partnership-trade-deal.ht $\mathrm{ml}$

Walt, S. M. (2011). The Myth of American Exceptionalism. Foreign Policy.

\section{Copyrights}

Copyright for this article is retained by the author(s), with first publication rights granted to the journal.

This is an open-access article distributed under the terms and conditions of the Creative Commons Attribution license (http://creativecommons.org/licenses/by/4.0/). 